\title{
Evaluation of the aquifer characteristic of Nanka Sands using hydrogeological method in combination with Vertical Electrical Sounding (VES)
} *OKORO, E I; EGBOKA, B C E; ONWUEMESI, A G

Department of Geological Sciences Nnamdi Azikiwe University P.M.B. 5025 Awka, Nigeria

*Email reallizkay@yahoo.com

\begin{abstract}
In this study, we have coupled surface geophysical method with pumping test results to provide a cost effective and efficient alternative in aquifer parameter estimation. Vertical Electrical Sounding (VES) was carried out at 40 sites in the study area for the identification of the vertical variation in subsurface lithology and for the characterization of the aquifer system of the study area. The interpretation of the VES data revealed 3 to 5 geoelectric units with the depth to aquifer varying from 7 to $108 \mathrm{~m}$ and the resistivity of the saturated layer varying between 42.9 and 8829 ohm-m. Using the geoelectric data, aquifer depth, hydraulic head and aquifer resistivity maps were prepare using appropriate software. Aquifer characteristics in the form of transmissivity and hydraulic conductivity calculated from interpreted VES results varied from 0.48 to $19.50 \mathrm{~m}^{2} /$ day and 0.06 to $3.75 \mathrm{~m} /$ day respectively. This coupling has proved useful and most valuable in areas of scarce data such as the study area. @ JASEM
\end{abstract}

The availability and access to fresh water is an important issue all over the world. Groundwater constitutes the only reliable water supply for drinking and irrigation purposes. It is exceptionally important as a source of relatively low-cost and high-quality municipal and domestic water supply in urban centers of the developing world. The understanding and management of groundwater in aquifer is still weak in many developing countries and investment in groundwater projects often founded inadequate quatitative/qualitativein data resulting in massive borehole failures.

Occurrence of groundwater in the study area is mainly in the friable Nanka Sands. Subsurface information inferred from geophysical survey gives more realistic picture of groundwater potential of an area (Amaresh et al., 2006). This study attempts to evaluate the aquifer characteristic of Nanka Sands using hydrogeological method in combination with Vertical Electrical Sounding (VES). The Vertical Electrical Sounding (VES) method has been successfully employed in sedimentary environment in watertable and hydraulic gradients estimation (Emenike, 2001 and Onwuemesi et al, 2006). Some authors have worked on the hydrogeology of Anambra Basin but no attempt have been made to couple geophysical method in hydrogeological studies in case of sparse data availability. Onwuemesi et al., 2006 established a formula for the computation of hydraulic gradient using 2-D polynomial curve fitting technique. Evaluation of the hydrogeological problems militating against meaningful exploitation and management of water resources in Enugu area was carried out by Egboka et al., 1990. Ofomah and Ezeigbo, 1997 studied the hydrolithologic characteristics of the various formations identified in Anambra Basin with the view of determining the groundwater potentials.

\section{MATERIALS AND METHOD}

The study area lies within latitudes $6^{\circ} 00 \mathrm{~N}$ and $6^{0} 18^{\prime} \mathrm{N}$ and longitudes of $6^{0} 45^{\prime} \mathrm{E}$ and $7^{0} 20^{\prime} \mathrm{E}$ covering area of about $1706 \mathrm{~km}^{2}$ within the Anambra Basin. The area falls within the rainforest belt of West Africa which has been severely reduced in many parts of the study area to Savannah vegetation through anthropogenic activities (Egboka et al., 1988). Two climatic conditions exist in Nigeria and the study area namely the rainy season and the dry season. While the rainy season in characterized by heavy thunderstorm that last from the months of April to October, the dry season extends from November to March with high temperature and dusty atmosphere. The mean annual

\footnotetext{
* Corresponding author: E-mail: reallizkay@yahoo.com
} 
rainfall is about 2000mm (Floyd, 1965). The high rainfall intensity and the concomitant large volumes of runoff are of significant environmental issue.

Vertical Electrical Sounding (VES) using Schlumberger electrode configuration was carried out at various locations in the study area. The acquired apparent resistivity data were inverted and interpreted in order to identify the different geoelectric units using RESIST automated inversion software. The geoelectrical parameters were co-related with available lithologic log of drilled sites and based on this co-relation, lithology was inferred at other sounding locations for identification of vertical variation in subsurface lithology. The depth and the resistivity values of the saturated layers obtained from the geoelectric sections and the calculated hydraulic heads at the respective (VES) locations were used to prepare watertable map, resistivity map and hydraulic heads map in ARC GIST software environment. Available information from pumping test analysis was combined with the VES results to calculate aquifer parameters $\left(\mathrm{T}_{\mathrm{c}}\right.$ and $\left.\mathrm{K}_{\mathrm{c}}\right)$. The study area is a significant part of Anambra Basin. Basin stratigraphy is largely a result of the paleohydrology of the region (Druhan et al., 2008). The main geologic units of the study area are the Nanka Sands (Eocene), which is overlain by Ogwashi-Asaba Formation (Oligocene) and underlain by Imo Shale (Paleocene) (Fig.1).

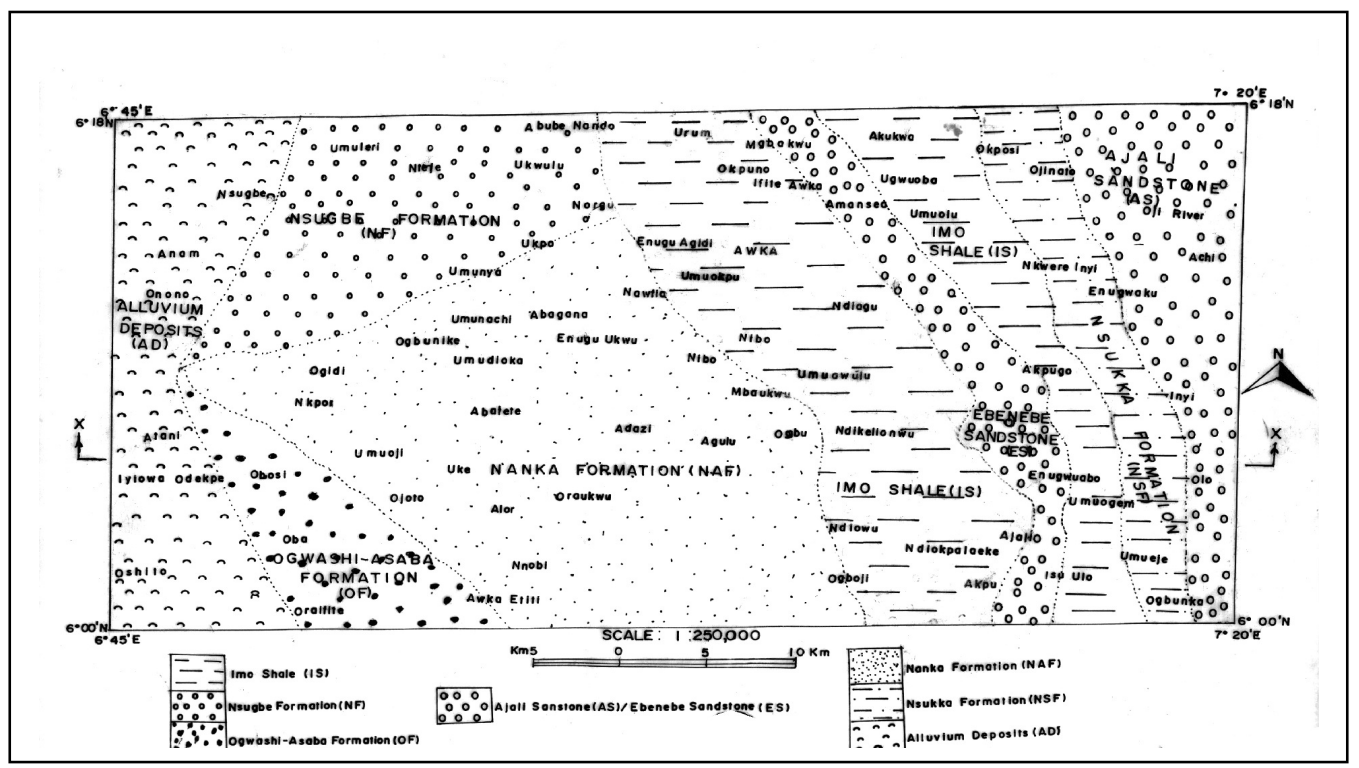

Fig. 1 Geologic map of the study area

Lithologically, the Nanka Sands consist of distinct units of sands, shale-siltstone and finely laminated shale. Sand subunits comprise uncemented, medium to coarse grained and pebbly quartz sand, with thickness varying from 50 to $90 \mathrm{~m}$ (Nwajide and Hoque, 1979). Topographically, the Nanka Sands form the North-South trending Awka-Umuchu-Orlu cuesta. The sandy units of the Formation form thick viable aquifer (Egboka et al., 1985). The Imo Shale which resulted from the major transgression of the Paleocene age consists of dark-grey to blush-grey shales, siltstone, mudstone and sandstone lenses. The main sandy facies is the Ebenebe Sandstone. The shale is highly fractured and fissile and lies east of the Nanka Sands. The area is drained by numerous surface waters in the form of Rivers, streams and lakes. While Idemili River and its tributaries drain the east of the study area, the Odo River drains the western part establishing a surface water divide.

The hydraulic characteristics of aquifers are important properties for both groundwater and 
contaminated land assessments and also for safe construction of engineering structures (Singh, 2005). Application of field hydrogeological method in aquifer parameter estimation is time consuming and capital intensive. In the alternative, surface geophysical method may provide rapid and effective techniques for groundwater exploration and aquifer evaluation.

In the present study, vertical electrical sounding was carried out in the porous media of Nanka Formation to establish the possible relationships between hydrogeophysical and hydrogeological studies in aquifer parameter estimation. The resistivity readings were processed to produce sections of the thickness and resistivity of subsurface electrical layers (Corriols et al, 2007). In a porous media such as the study area, hydrogeological properties of the aquifers do not generally vary rapidly as a result, direct linear relations between resistivity and hydraulic parameters ( $\mathrm{K}$ and $\mathrm{T}$ ) are expected to exist.

Hydraulic conductivity and aquifer depth are fundamental properties describing subsurface hydrology. Many investigation techniques are commonly employed with the aim of estimation of spatial distribution of hydraulic parameters. Field estimations of these parameters are not always available and usually appear to be problematic (Mendosa et al., 2003, and Zecharia et al., 1988). The integration of aquifer parameter calculated from the existing/existed boreholes and surface resistivity parameters extracted from surface electrical measurements can be highly effective not only for aquifer hydraulic conductivity estimation but also for group of hydraulic parameters. Correlation between hydraulic and electrical aquifer properties can be possible, as both properties are related to the pore space structure and heterogeneity of the medium under study Kelly, 1977, Mazac et al., 1988 and Huntley, 1986.
The application of surface geophysical methods in combination with pumping tests at a few locations provides a cost effective and efficient alternative to aquifer parameter estimation (Soupios et al., 2005). The transmissivity ( $\mathrm{T}$ ) of aquifer is related to the field hydraulic conductivity (K) by the equation.

$\mathrm{T}=\mathrm{K} b$

Hence, $\mathrm{K}=\mathrm{T} \mathrm{b}^{-1}$

According to Niwas and Singhal (1981) in a porous medium

$\mathrm{T}_{\mathrm{C}}=\mathrm{KR} \rho^{-1}$

$\mathrm{T}_{\mathrm{c}}=\mathrm{KR} \rho^{-1}$

$=\mathrm{KS} \rho$

Where $\mathrm{T}_{\mathrm{c}}=$ calculated transmissivity $\left(\mathrm{m}^{2}\right.$ day $)$ from VES

$\mathrm{R}=$ Total transverse resistance $\left(\mathrm{ohm}-\mathrm{m}^{2}\right)$

$\mathrm{S}=$ Total longitudinal conductance $\left(\mathrm{ohm}^{-1}\right)$

$\rho=$ Resistivity of the saturated layers (ohm-m)

$\mathrm{K}_{\mathrm{c}}=\mathrm{T}_{\mathrm{cb}}{ }^{-1}$

Where $\mathrm{K}_{\mathrm{c}}=$ calculated hydraulic conductivity mday $^{-1}$ from VES result

$\mathrm{b}=$ thickness of the saturated layer $(\mathrm{m})$.

\section{RESULTS AND DISCUSSION}

For the 40 VES measurements carried out for this research, only eight (8) locations had valuable information from previous pumping test of existing borehole for the accurate estimation of hydraulic parameters. The calculated hydraulic conductivity Kc and transmissivity Tc from the interpreted VES data using equation (2) and (3) are presented in Table 1.

The transmissivity Tc values calculated from the VES results range from 0.48 to $19.50 \mathrm{~m}^{2} /$ day while the equivalent obtained from pumping test vary from 1.07 to $33.74 \mathrm{~m}^{2} /$ day. 
Table 1. Aquifer parameters estimated from geophysical data

\begin{tabular}{|l|l|l|l|l|l|l|l|l|}
\hline $\begin{array}{l}\text { VES } \\
\text { NO }\end{array}$ & B & $\begin{array}{l}\text { P } \\
(\text { Ohm-m })\end{array}$ & $\begin{array}{l}\text { Longitudinal } \\
\text { Conductance }\end{array}$ & $\begin{array}{l}\text { Transverse } \\
\text { Resistance }\end{array}$ & $\begin{array}{l}(\mathrm{K}) \\
\mathrm{m} / \mathrm{day}\end{array}$ & $\begin{array}{l}(\mathrm{T}) \\
\mathrm{m}^{2} / \text { day }\end{array}$ & $\begin{array}{l}\mathrm{Kc} \\
\mathrm{m} / \mathrm{day}\end{array}$ & $\begin{array}{l}\text { Tc } \\
\left(\mathrm{m}^{2} / \mathrm{day}\right)\end{array}$ \\
\hline 2 & 34.6 & 295 & 0.1173 & 10207 & 0.17 & 9.51 & 0.17 & 5.88 \\
\hline 5 & 5.2 & 659 & 0.0079 & 3426.8 & 3.73 & 33.74 & 3.75 & 19.50 \\
\hline 6 & 1.9 & 407 & 0.0047 & 773.3 & 0.25 & 1.50 & 0.25 & 0.48 \\
\hline 12 & 34.3 & 606 & 0.0566 & 20785.8 & 0.29 & 1.07 & 0.29 & 9.95 \\
\hline 15 & 15.2 & 1130 & 0.0135 & 17176 & 0.29 & 2.34 & 0.29 & 4.41 \\
\hline 22 & 53.8 & 1205 & 0.0446 & 64829 & 0.12 & 3.58 & 0.12 & 6.46 \\
\hline 29 & 21.6 & 106 & 0.2038 & 2289.6 & 0.22 & 1.85 & 0.22 & 4.75 \\
\hline 18 & 35.5 & 1965 & 0.0181 & 69757.6 & 0.06 & 1.07 & 0.06 & 2.13 \\
\hline
\end{tabular}

Generally, the values of the calculated transmissivity (Tc) are higher than the values obtained from pumping test analysis (Table I), except in a situation where two aquifer systems were identified from geoelectric sections. The high values of the calculated Tc are due to calculations from the entire saturated thickness of the aquifer. The hydraulic conductivity Kc values estimated from the VES results range from 0.06 to $3.75 \mathrm{~m} /$ day. These values compared favourably well with those obtained from pumping test analysis. The Tc and $\mathrm{Kc}$ values also compared well with the value obtained by Ezeigbo et al., 1995 from pumping test in Table 2 for the lower confirmed aquifer systems of Nanka sands.

Table 2: $\mathrm{K}$ and $\mathrm{T}$ values for the lower confined aquifer system of Nanka Sands from pumping test analysis (Ezeigbo and Obiefuna 1995)

\begin{tabular}{|l|l|l|l|}
\hline Loccation & $\mathrm{B}(\mathrm{m})$ & $\begin{array}{l}\text { Mean } \\
\mathrm{K}(\mathrm{m} / \mathrm{h})\end{array}$ & $\begin{array}{l}\text { Mean T } \\
\left(\mathrm{m}^{2} / \mathrm{h}\right)\end{array}$ \\
\hline Ogbunike & 15.81 & 0.20 & 3.25 \\
\hline Ukpo & 15.0 & 0.03 & 0.45 \\
\hline Otuocha & 16.3 & 0.62 & 10.11 \\
\hline Abatete & 15.0 & 0.16 & 2.40 \\
\hline
\end{tabular}

The result of the hydrogeophysical investigation in the Nanka Formation reveal 3 to 5 geoelectric units indicating confined aquifer system in the formation. The sandstone units at a depth of 7 to $108 \mathrm{~m}$ constitute the aquifer unit in the study area. The saturated layers are confined in places by shale layer. Aquifer parameters ( $\mathrm{T}$ and $\mathrm{K}$ ) of Anambra Sedimentary Basin are yet to be established. Since well-drilling for aquifer parameters calculation is often prohibitively expensive, determining these parameters from VES becomes a cost effective alternative. Although VES have limitations in areas of complex geology and topography, they are suitable for deep geophysical investigation. Based on the obtained result, the integration of hydrogeophysical data and available pumping test data have proved to be rather significant in the quantitative estimation of aquifer parameters. The interpreted resistivity data were transformed into aquifer parameters $(\mathrm{T})$ and $(\mathrm{K})$ for VES locations with valuable pumping test data. The calculated aquifer parameters were consistent and well defined within the range of observed aquifer parameters obtained from pumping test. The calculated transmissivity $(\mathrm{Tc})$ values vary between 0.48 to $19.50 \mathrm{~m}^{3} / \mathrm{h}$ while the calculated hydraulic conductivity $(\mathrm{Kc})$ values vary from 0.06 to $3.75 \mathrm{~m}^{2} / \mathrm{h}$.

\section{REFERENCES}

Amaresh, K.S., Raviprakash, S., Mishra, D., and Singh, S., 2006: Groundwater potential modeling in Chandraprabha Subwater shed, UP using Remoting sensing, geoelectrical and GIS. www.gisdevelopment.net. Retrieved Aug. 2007.

Corriols, M. and Dahlin, T. 2008. Geophysical Characterization of the Leon-Chinandega Aquifer. Hydrogeology J. 16 (2): 355.

Druhan, J.L. and Hogan, F.J. 2008. Hydrogeological controls on groundwater recharge and salinization. A geochemical analysis of the Northern Hueco Bolson Aquifer Texa, USA . Hydrogeology J. 16 (2): 283

Egboka, B.C.E. and Onyebueke, F.O. 1990. Acute Hydrogeological problems vis-a-via planning and management in a developing economy. A case study of the establishment of aquifer parameters using Enugu Area. Nig Assoc. of Hydrogeo. J. (2): 43-55.

Egboka, B C E; Nwankwo, G. I (1985). The hydrogeological and 
geotechnical parameters as agents of gully type of erosion in the rainforest belt of Nigeria. Afric. Earth Sci. J. (3 ): 417-425.

Egboka, B.C.E. and Orajaka, I.P.1988. Soil and Gully erosion models for effective control programs. Geoforum J. 18 (3): 333-341.

Egboka, B.C.E., 1988. Hydrogeological provinces of Nigeria. Water quality Bull. 13 (4): 117-125

Emenike, E.A., 2001: Geophysical Exploration for groundwater in a sedimentary environment: a case study from Nanka over Nanka Formation in Anambra Basin, Southeastern, Nigeria. Global Jour. of pure and applied Sciences, 7 (1): 56

Ezeigbo, H.I. and Nwankwo, G.I. 1995. An evaluation of the groundwater resources of Ogbunike area and Environs, Anambra State S.E., Nigeria. Water Res. J. 16 ( 1\&2).

Foldy, B., 1965. Soil erosion deterioration in eastern Nigeria. Nig. Geogr.J. 18 (1):33- 44.

Huntley, D., 1986. Relations between permeability and electrical resistivity in granular aquifers. Gwater J. 24 (4): 466-474.

Kelly, W.E., 1977. Geoelectrical sounding for estimating aquifer hydraulic conductivity. G.water J. 50 (6): 420-425

Mazac, O., Cislerova, M. and Vogel, T. 1988. Application of geophysical methods in describing spatial variability of saturated hydraulic conductivity in the zone of aeration. J. of Hydrology 103: 117-126

Mendosa, F.G., Steenhuis, S.T., Todd, W.M., and Parlange, J.Y. 2003. Estimating basin wide hydraulic parameters of a semi-arid mountainous water shed by recession-flow analysis. J. of hydrology pp 57-69

Nwajide, S.C. and Hoque, M.1979. Gullying processes in southeastern Nigeria. The Nig. Geogr. J. 8 (1): 45-59.

Ofoma, J.C.and Ezeigbo, H.I. 1997. Hydrogeological evaluation of the Anambra Basin, Southeastern Nigeria. Water Resources
(NAH) J. 8 (1\&2)

Onwuemesi, A.G. and B.C.E. Egboka, 2006. 2-D Polynomial curve fitting techniques on watertable, and hydraulic gradients estimations in parts of Anambra Basin, Southeastern Nigeria, Natural and Applied Sci. J. 7 (1\&2) pp 6-13.

Prokop, G. 2003. Sustainable management of soil and groundwater resources in urban areas. Proceedings of the $2^{\text {nd }}$ IMAGE TRAIN cluster meeting, Krakow, Poland.

Reyment, R.A., 1965. Aspect of the Geology of Nigeria, Ibadan University press Ibadan pp145.

Singh, K.P., 2005. Nonlinear estimation of aquifer parameters from surficial resistivity measurements. Hydro. Earth Sci. Discuss 2. pp 718-726. www.copernicus-org/Egu/hess/2/917.

Soupios, P.M., M. Kouli, F. Vallianatos, A. Vafidis and G. Stavroulakis, 2005. Hydraulic parameters from surface geophysical methods: Keritis Basin in China-Crete. www.geophysicsonlinse.edu. Retrived Sept. 2007.

Zecharias, Y.B. and W. Brutsaert, 1988. Recession characteristics of groundwater outflow and baseflow from mountainous watersheds, water resources research, 24 (10) pp $1651-1658$

Zhou Guang-de. Design \& applied research of building energy conservation. China Building Materials Science \& Technology, 2009, (2):65-66 (in Chinese)

TAO Lun-kang. The Ethics Foundation of Legislation for Energy Conservation and Reduced Emissions. Plating \& Finishing, 2009, (5):7-12 (in Chinese)

Li Shen. Wastewater Treatment Innovation and Energy Saving and Pollution Reduction in a Dyeing and Finishing Plant. Textile Dyeing and Finishing J., 2009, (6):41-44 (in Chinese)

Zhang Yong-jia. EMC Model and Its Generalization and Application in the Cause of Energy-saving and Emission Reduction. Shenhua Science and Technology, 2009, (1):91-94 (in Chinese) 